\title{
Rapid and sensitive methods for detection of Allorhizobium vitis, causal agent of grapevine crown gall
}

\author{
Khaoula Habbadi ${ }^{1,2,3}$, Basma Benbrahim ${ }^{2,3}$, Abdellatif Benbouazza ${ }^{2}$, Rachid Benkirane ${ }^{1}$, \\ El Hassan Achbani ${ }^{2}$
}
${ }^{1}$ Laboratoire de Botanique, Biotechnologie, et Protection des Plantes, Faculté des Sciences, Kenitra, Maroc;
${ }^{2}$ Laboratoire de recherche et de protection des plantes URPP- INRA-Meknès, Maroc;
3 Laboratoire de Biotechnologie microbienne, Faculté des Sciences et Techniques de Fès.

\section{Corresponding author:}

El Hassan Achbani, Laboratoire de recherche et de protection des plantes URPP- INRA-Meknès, Maroc, Tel. : (+ 212) 535300190 ; Fax: (+212) 535300244 ; E-mail: achbanieh@gmail.com

Habbadi Khaoula, Laboratoire de recherche et de protection des plantes URPP- INRA-Meknès, Maroc,Laboratoire de Botanique, Biotechnologie, et Protection des Plantes, Faculté des Sciences, Kenitra, Maroc ; Tel : (+ 212) 635083373 ; Email : khaoula405@gmail.com

\begin{abstract}
A rapid method and sensitive methods for extraction of bacterial DNA from pure culture and directly from plant materiel were compared in polymerase chain reaction with specific primers VCF3/VCR3 to see the reliable method that can used in the detection of tumorigenic strain of Allorhizobium vitis causal agent of grapevine crown gall. From the three tested methods of DNA extraction from pure culture, the alkaline method is the most effective technique for the extraction presenting a high sensitivity with a detection threshold equal to $5.10^{4} \mathrm{CFU} / \mathrm{ml}$. Five different protocols for extracting bacterial DNA from plant tissues of infected tomato, based on the use of an extraction buffer, were tested to see its usefulness in detecting pathogenic strain of A. vitisS4. Two protocols based on the use of Triton X-100 and Tween 20 were efficient for detecting A. vitis $S 4$ directly from tomato tumors with a sensitivity of $10^{3} \mathrm{CFU} / \mathrm{ml}$ for the both protocols. Consequently, these protocols were proposed as specific protocols for the detection of tumorigenic strain of A. vitis from symptomatic and asymptomatic plants.
\end{abstract}

Keywords - Crown gall, grapevine, Allorhizobium vitis, DNA extraction, detection, detection threshold.

\section{INTRODUCTION}

Crown gall of grapevine caused by Allorizobium vitis (Moussavi et al., 2014, 2015), previously named Agrobacterium vitis (Ophel and Kerr 1990); is an economically important disease and one of the most serious bacterial disease affecting grape production in several countries (Burr and Otten, 1999). The tumorigenicity of A. vitis is an encogenes transfer into plant cells of the T-DNA (transferred DNA), part of a large tumor-inducing (Ti) plasmid (Thomashow et al. 1984).The T-DNA integrated into the plant cell genome, contains gens responsible for the biosynthesis of hormones (auxins and cytokines) leading to gall development and genes coded for biosynthesis of opines used as specific carbon and nitrogen sources for A. vitis development (Lacroix and Citovsky, 2013). The development of galls obstruct vascular tissue and restrict movement of water and nutrients into the vine above the gall, which affect grapevine growth and yield (Schroth et al., 1988).

A. vitis is adapted to survive in the plants tissues without causing tumors until conditions becomes favorable for gall development. Therefore, the disease spreads out by asymptomatic propagating materials (Kuzmanovic et al., 2014) which is necessary to develop a reliable detection methods of the pathogen in both symptomatic and asymptomatic plant materials and in the soil to efficiently prevent the disease (Bini et al., 2008). Generally, the detection methods of $A$. vitis are based on their isolation on the semiselective culture media and pathogenicity tests but these methods can take many weeks for results (Johnson et al., 2013, Shams et al., 2012). Polymerase chain reaction (PCR) it's the most reliable technique improve sensitivity, specificity and rapidity for the detection of bacteria which targets gens that is found only in A. vitis by the use of specific primers(Johnson et al., 2013; Shams et al., 2012, 2013). 
Several PCR protocols have been developed and successfully used for detection of tumorigenic strains of A. vitis directly from plant hostswith the use of primers, which target gens localized on Ti plasmid,vir or TDNAregions (Bini et al., 2008). Generally,the methods of extraction of bacterial DNA from plant tissues are based to the use of a DNA purification Kit specific to A. vitis and characterized to inhibit the action of plant polyphenols that inhibit the PCR reaction (Bini et al., 2008). This method is very expansive and need several steps for purification of the DNA; for this reason, many study work was conducted to develop others techniques of DNA extraction directly from infected plants (Llop et al., 1999, Szegedi and Bottka, 2002).

The main purpose of this study was to compare the extraction procedures of DNA from pure culture for efficient routine detection of $A$. vitis and to evaluate and optimize protocols of detection of A. vitis used Bio-PCR and PCR reaction directly for infected plant with the study of threshold of detection of the pathogen.

\section{MATERIAL AND METHODS}

\section{Bacterial strain and culture conditions}

The bacterial strain used in this study is A. vitis strain S4 (sequenced strain) isolated from black raspberry in Hungary (Popoff et al., 1984). A. vitis S4 was cultivated on MG medium (Moore et al., 2001)(D-mannitol, 5g/L; L-glutamic acid, $2 \mathrm{~g} / \mathrm{L} ; \mathrm{KH}_{2} \mathrm{PO}_{4}, 0.5 \mathrm{~g} / \mathrm{L} ; \mathrm{NaCl}, 0.2 \mathrm{~g} / \mathrm{L}$; $\mathrm{MgSO}_{4} \times 7 \mathrm{H}_{2} \mathrm{O}, 0.2 \mathrm{~g} / \mathrm{L}$; Yeast extract, $0.5 \mathrm{~g} / \mathrm{L} ;$ Agar, $15 \mathrm{~g} / \mathrm{L} ; \mathrm{pH}=7$ ) and incubated, for 24 hours, at $28^{\circ} \mathrm{C}$.

\section{Pathogenicity and hypersensibility tests}

The pathogenicity of strains A. vitis $\mathrm{S} 4$ was studied by inoculating-plants of tomato (Solanum lycopersicum L.). The inoculation was made by $10 \mu \mathrm{l}$ of suspension $\left(10^{7} \mathrm{CFU} / \mathrm{mL}\right)$ of 24 hours bacterial culture in stem internodes of tomato 2-3 weeks after transplanting. Inoculated plants were maintained in greenhouse at $27^{\circ} \mathrm{C}$ during 3-4 weeks.

The hypersensibility reaction was determined on tobacco (Nicotiana tabacum cv. Xanthi). $200 \mu \mathrm{l}$ of bacterial suspensions $\left(10^{7} \mathrm{CFU} / \mathrm{ml}\right)$ were infiltrated ontobacco leaf by a needleless syringe. Sterile water was used as a negative control. The tobacco plants were kept in a growth greenhouse. Development of necrosis was scored over a period of 4 to 5 days.

\section{DNA extraction from pure culture}

Three extraction procedures were used to obtain DNA for Bio-PCR analysis:

The first protocol was based to use alkaline method (Shams et al., 2013). From bacteria grown overnight at $28^{\circ} \mathrm{C}$ in MG medium, one colony of A. vitis $\mathrm{S} 4$ was mixed with $10 \mu \mathrm{l}$ of $\mathrm{NaOH}(20 \mathrm{mM})$ and incubated at $37^{\circ} \mathrm{C}$ for 5 minutes. The A. vitis lyses cells were stored at $4^{\circ} \mathrm{C}$ until they use.

The second protocol was based on the lysis of the bacterial cells by heating a bacterial suspension of $10^{8} \mathrm{CFU} / \mathrm{ml}$ at $100{ }^{\circ} \mathrm{C}$ for $15 \mathrm{~min}$. the lyses cells were stored at $4{ }^{\circ} \mathrm{C}$ until they use (Hannou et al., 2013).

The third protocol is based on the lysis of the cells by thermal shock by heating the bacterial suspension for 15 min at $100{ }^{\circ} \mathrm{C}$ then cooling in ice for $5 \mathrm{~min}$ and centrifuging at $10000 \mathrm{~g}$ for $1 \mathrm{~min}$. The resulting supernatant was used for PCR (Pastrick and Rainay, 1999; Ameur et al., 2014).

\section{Bio PCR-pTi}

Specific primers (GGCGGGCGYGCYGAAAGRAARACYT) and VCR3 (AAGAACGYGGNATGTTGCATCTYAC) were used to identify pathogenic strains of $A$. vitisby the detection of plasmids (pTi); they amplify a DNA fragment of 414bp of the virCl and virC2 genes (Kawaguchi, 2009). Standard PCR was carried out in a $60 \mu 1$ reaction volume containing 38.6 $\mu \mathrm{L} \mathrm{H}_{2} \mathrm{O}, 6 \mu \mathrm{l}(2 \mathrm{mM})$ DNTPs, $1.2 \mu \mathrm{l}(2 \mathrm{mM}) \mathrm{MgCl}_{2}$, $3 \mu \mathrm{l}$ DMSO (Dimethyl sulfoxide), $1 \mu 1(10 \mu \mathrm{M})$ of each primer, $0.2 \mu 1$ Taq DNA polymerase (Invitrogen, France) and $3 \mu 1$ of lyses cells from each extraction protocols were tested. In order to test the possibility to detect A. vitis without carring extraction of the DNA, two others methods were tested; the first was to add a small colony directlyin master mix using toothpick; and the second method was to add $3 \mu 1$ of a bacterial suspension of $\left(10^{8}\right.$ $\mathrm{CFU} / \mathrm{ml}$ ) into the mix. In all five protocols were tested to detect $A$. vitis.

The PCR was performed using the following program: initial denaturation at $95^{\circ} \mathrm{C}$ for $5 \mathrm{~min}$, followed by 35 cycles of denaturation at $95^{\circ} \mathrm{C}$ for $1 \mathrm{~min}$, annealing at $57^{\circ} \mathrm{C}$ for $1 \mathrm{~min}$ and extension at $72^{\circ} \mathrm{C}$ for $1 \mathrm{~min}$, followed by an additional extension at $72^{\circ} \mathrm{C}$ for $3 \mathrm{~min}$. Electrophoresis was performed in $1.5 \%$ agarose gel. The gel was soaked with ethidium bromide. Fragments were visualized with an ultraviolet (UV) transilluminator, and the gel was photographed.

\section{Bacterial DNA extraction from tomato tumors}

Five protocols were tested to obtain DNA from tomato tumors for PCR analysis. The samples used in this test was made from the tumors obtained during the production of symptoms on tomato plants. Firstly, the tumors were washed in running water and tumor fragment surface were disinfected with $70 \%$ ethanol. The necrotic tissues were removed; and tumor was cut in small fragment. The pieces of tumor were ground in $2 \mu 1$ of sterile distilled water using a mortar and pestle to isolate the pathogen from plant tissues. After incubation during 30min, the macerates were filtered using sterile filter paper. 
The first protocol used in this study to extract the DNA from the macerates was been described by Bereswill et al. (1992). The macerates were shaken for two hours in a $0.9 \% \mathrm{NaCl}$ solution. The supernatant was centrifuged during $10 \mathrm{~min}$ at $10000 \mathrm{~g}$, the pellet was resuspended in $0.1 \mathrm{ml}$ of sterile water, and $10 \mu \mathrm{l}$ was used for PCR-pTi analysis.

The second protocol was described in the study work of Llop et al. (1999). 500 $\mu 1$ of macerates were placed into an Eppendorf and centrifuged at $10000 \mathrm{~g}$ for $10 \mathrm{~min}$. The pellet was resuspended in $500 \mu 1$ extraction buffer (200 $\mathrm{mM}$ Tris HCL $\mathrm{pH} 7.5,250 \mathrm{mM} \mathrm{NaCl}, 25 \mathrm{mM}$ EDTA, $0.5 \%$ SDS, $2 \%$ PVP), vortexed and left for 1 hour at room temperature with continuous shaking. Then it was centrifuged at $5000 \mathrm{~g}$ for $5 \mathrm{~min}, 450 \mu \mathrm{l}$ of the supernatant were taken $450 \mu 1$ isopropanol added, mixed and left for 1 hour at room temperature. The mixture was centrifuged and the pellet dried under vacuum. Finally, it was responded in $100 \mu \mathrm{l}$ water.

For the third protocol, we use the modified extraction technic by Taylor et al. (2001). 500 $\mu 1$ of macerates were placed into an Eppendorf and centrifuged at 10000g for $10 \mathrm{~min}$. the pellet was suspended in $500 \mu \mathrm{l}$ of plant extraction buffer (140 mM NCL, $50 \mathrm{mM} \mathrm{KCl,} 0.05 \%$ Tween 20, 2\% PVP and 0.4\% BSA). The mixture was left at room temperature during $15 \mathrm{~min}$ and stored in $4^{\circ} \mathrm{C}$ until use.

The fourth technic tested in this study was described in the study work of Szegedi and Bottka (2002). 1ml of the macerate was placed in Eppendorf and centrifuged at $18000 \mathrm{~g}$ in $4^{\circ} \mathrm{C}$ for $15 \mathrm{~min}$. the pellet was suspended in $100 \mu 1$ of sterile water in mixture with Triton X-100 (1\%) (V:V) and heated at $95^{\circ} \mathrm{C}$ for $10 \mathrm{~min}$.

The last protocol tested in this study was the same protocol described previously but with some modifications. The Triton X-100 solution was replaced with Tween $20(0.1 \%)$. This protocol is based on the work of Bini et al. (2008).

\section{PCR analysis}

For all extraction protocols from tumors, PCR analysis was made using specific primers of VircC1 and VirC2 gens (VCF3 and VCR3). The reactional mix was prepared separately for each protocol (Table 1). PCR program was performed with the same condition as before.

\section{Determination of the detection threshold of $A$. vitis}

In order to evaluate the sensitivity of detection protocols of A. vitis by Bio-PCR, two bacterial suspension of $10^{9}$ $\mathrm{CFU} / \mathrm{ml}$ were prepared, one in sterile water and the other in lysis solution of $\mathrm{NaOH}(20 \mathrm{mM})$. From the two bacterial suspensions, serial dilutions were made to a concentration of $10^{2} \mathrm{CFU} / \mathrm{ml}$. The detection threshold of A. vitis was also made for the macerates obtained from the previous tests. The PCR was performed using specific primers VCF3 and VCF3 and according to the same condition as before.

\section{RESULTS \& DISCUSSION}

Pathogenicity and hypersensibility tests

A. vitis strain $\mathrm{S} 4$ was tested for the ability to induce hypersensitive response (HR) on tobacco and tumors in tomato. The tested strain is capable to cause HR in leaf of tobacco after 2 days of inoculation (Figure 1A) and able to induce tumor on stems of inoculated tomato within 20 days of incubation in greenhouse (Figure 1B). The capacity of this strain to induce gall development in tomato is related to the presence of pTi plasmid, which is an important element for the pathogenicity and tumorigenicity of $A$. vitis strains (Shams et al., 2012). The necrosis in leaf of tobacco results in rapid cell death and it is a part of the plant defense response against pathogens (Rodriguez-Palenzuela et al., 1991, Heath, 1998). The HR induced in leaf of tobacco it resembles a disease reaction in grape tissues infected with $A$. vitis in natural conditions. It has been demonstrated that several plant pathogenic bacteria that cause necrosis on host plant are able to induce HR to another plants (Alfano and Collmer, 1996). The ability of $A$. vitis to induce HRis due to the capacity of this strain to produce specific enzyme, Plygalacturonase (PG) (Rodriguez-Palenzuela et al., 1991). Other research have demonstrated that when the concentration of $A$. vitisis greater than approximately $10^{6}$ $\mathrm{CFU} / \mathrm{ml}$, the A. vitis was able to cause necrosis (Herlache, 1999).

\section{Bio PCR-pTi}

The effectiveness of three protocols of the DNA extraction and two others methods without the extraction of the DNA, used for detection of A. vitis $\mathrm{S} 4$ from pure culture, was evaluated by molecular test with the primers VCF3/VCR3(Figure 2). The results show that a 414 bp fragment of virC1-virC2 gene (Sawada and Tsuchiya, 2003) was amplified with all the tested protocols of DNA extraction and without extraction using only a colony or a bacterial suspension; therefore, these protocols can be used for the different molecular tests to characterize and $\operatorname{detect} A$. vitis strains. Moreover, the use of virC primers are able to detect pathogenic strains of $A$. vitis possessing pTi plasmid (Kawaguchi, 2009; Kumagai and Fabritius, 2008); and were used in several study work to identify tumorigenic strain of A. vitis in several countries(Kuzmanovic and al., 2012; Lamovšek et al., 2014).

\section{Detection of $\boldsymbol{A}$. vitis $\mathbf{S} 4$ from tomato tumors}

The detection of $A$. vitis directly from infected plant represents an important technique for the diagnostic of the disease. In this work, five different protocols were used to extract the DNA from tumors produced in tomato plants. 
Moreover, to compare these protocols the macerate, the enriched macerate with the PBS and pure colonies were used as a DNA template. The obtained results show the presence an expected size amplicon (414 bp) which amplified using the protocols 3 (Taylor et al., 2001), 4 (Szegedi and Bottka, 2002) and 5 (Bini et al. 2008) of extraction of DNA from plant tissues and also from enriched macerate (Figure 3). However, we cannot detect A. vitis with use of the protocol1(Bereswill et al., 1992) and 2 (Llop et al., 1999) of DNA extraction from infected tomato and also the direct detection from pure macerate.

The three proctolos validated for the detection of $A$. vitis directly from plant tissues are based on the use of a buffer of extraction (Tween 20, the polyvinylpyrrolidone and bovine serum albumin) or only the detergent (Triton X100 and Tween 20). These compounds can eliminate the inhibitors of PCR and also can cause lysis of bacterial cells. Plant compounds and in particularly the polyphenols and polysaccharides (De Boer et al., 1995) may limit the amplification of the bacterial DNA fragment extracted from plant material. Therefore, in the presence of these compounds, several authors suggest that the DNA should be purified using 2-mercaptoethanol or polyvinylpyrrolidone or by the use of commercial kits (Bereswill et al., 1992; Eastwell et al., 1995; Cubero et al., 1999; Taylor et al., 2001).

In the research work of Eastwell et al. (1995) they found that the bacterial lysis cells in situ in grapevine followed by DNA purification was more effective to detect $A$. vitis than then analysis of bacteria suspended in water. This observation may be due to the fixation of the bacteria to the cell walls of the grapevine cell. Moreover, in the study work of Kaufmann et al. (1996) they showed that the use of immunocapture culture of plant extract improve the sensibility and reliability of the method.

\section{Determination of the detection threshold of $A$. vitis}

For a large application of PCR for the detection of $A$. vitis, it is necessary to develop a rapid and simple protocol for the extraction of DNA for amplification and in the same time, the protocol must be sensitive for the detection of bacteria on low concentrations. For this reason, an evaluation test of the detection threshold of each protocol (from pure culture and macerate) was mad to know the minimum concentration detectable by various protocols applied to the $A$. vitis strain. Different concentrations of DNA ranging from $10^{9} \mathrm{CFU} / \mathrm{ml}$ to $10^{2}$ $\mathrm{CFU} / \mathrm{ml}$ were test for the evolution of the detection threshold.

The determination of detection threshold by Bio-PCR of different protocols of DNA extraction indicate that the three protocols of lysis cell from pure culture show different results. For the alkaline method of DNA extraction, the detection threshold was determinate in a concentration equal to $5.10^{4} \mathrm{CFU} / \mathrm{ml}$ (figure $4 \mathrm{~A}$ ). For the protocol of heating bacterial suspension, the detection threshold correspond to the concentration equal to $5.10^{6}$ $\mathrm{CFU} / \mathrm{ml}$ (Figure 4B). Moreover, for the third protocol of thermal shock the detection threshold correspond to the concentration $10^{5} \mathrm{CFU} / \mathrm{ml}$ (Figure 4C). From the three tested protocols, the alkaline method was the more sensitive method for detection of $A$. vitis from pure culture. The alkalinity and high temperature cause the lysis of well cells and therefore the liberation of the DNA in the solution. The sensitivity of alkaline protocol can be explained by the additional $\mathrm{NaOH}$ property of the hydrogen bond perturbation between the DNA base pairs, which denatures genomic and plasmid DNA and allow their amplification. However the alkaline method is only used for the pure culture and isolated bacterial cells and cannot be used for the detection of $A$. vitis from plant material. In the study work of Burr et al. (1999) and Cubero et al. (1999) the detection threshold was determinate for 150 to 200 cells. Szegedi and Bottka (2002) were demonstrated that the detection threshold is equal to $10^{5} \mathrm{CFU} / \mathrm{ml}$ using the protocol of heating bacterial suspension in sterile distillated water and in Triton X-100. The Triton X-100 solution was more effective than sterile distillated water.

For the determination of detection threshold, theprotocol 4 and 5 used for the extraction of DNA of A. vitis from plant material and based on the use of Triton X-100 and Tween 20 were selected due to the simplicity and rapidity of these techniques. Therefore, it is necessary to determinate their sensitivity in order to identify their detection threshold. The sensitivity evaluation test of each protocol was carried using a decimal dilution of the macerate solution. The obtained results of specific PCRpTi show that tested protocols are able to detect bacteria with concentration equal to $10^{3} \mathrm{CFU} / \mathrm{ml}$ (Figure 5). These techniques can identify $A$. vitis with a low concentration from macerate that contain different bacterial species.

\section{CONCLUSION}

In conclusion, results obtained in the present work show that use of alkaline method for the extraction of DNA from pure culture are the reliable and sensitive method can be used in several study for molecular characterization and detection of A. vitis isolates. Moreover, the use of direct techniques to detect $A$. vitis from plant materials by specific PCR are important issues that can be used for the detection of the pathogens from symptomatic and asymptomatic grapevines.

\section{ACKNOWLEDGEMENTS}

This study was supported by the PRAD 14-08 project "Biological control of Agrobacterium vitis, the causal 
agent of Crown gall on grapevines" and the regional center of the National Institute for Agricultural Research Meknes (INRA). The authors would like to thank Ilyass MAAFA (Laboratoire de Botanique, Mycologie et Environnement, Faculté des Sciences de Rabat, Université Mohamed V) and Soumia Sadik (URPP- INRA-Meknès, Maroc) for reading the manuscript and providing suggestions.

\section{REFERENCES}

[1] Alfano JR and A Collmer (1996) Bacterial pathogens in plants: Life up against the wall. Plant Cell 8:1683-1698.

[2] Ameur A, MM Ennaji, S Cesbron, C Manceau, N Rhallabi, EH Achbani (2014) Characterization of Moroccan Population of Erwinia amylovora, the Causal Agent of Fire Blight on Rosacea. Int J Biosci Biochem Bioinforma 4 (3) :200-203.

[3] Bereswill ., A Pahl, P Bellemann, W Zeller and K Geider (1992) Sensitive and species-specific detection of Erwinia amylovora by polymerase chain reaction analysis. Appl EnvirMicrobio 58(11): 35223526.

[4] Bini F, K Geider and CBazzi (2008) Detection of Agrobacterium vitis by PCR using novel virD2 gene specific primersthat discriminate two subgroups. Eur J Plant Pathol122: 403-411.

[5] Burr TJ and L Otten (1999) Crown gall of grape: biology and disease management. Annu Rev Phytopathol 37:53-80.

[6] Cubero J, MC Martinez, P Llop and MM Lopez (1999) A simple and efficient PCR method for the detection of Agrobacterium tumefaciens in plant tumours. J Appl Microbiol 86: 591-602.

[7] De Boer SH, LJ Ward, X Li and S Chittaranjan (1995) Attenuation of PCR inhibition in the presence of plant compounds by addition of BLOTTO. Nuc Aci Res 23(13): 2567-2568.

[8] Eastwell JC, LU Willis and ID Cavileer (1995) A rapid and sensitive method to detect Agrobacterium vitis in grapevine cuttings using the polymerase chain reaction. Pla Dis 79:45-49.

[9] Hannou N, P Llop, D Faure, M López and M Moumni (2013) Characterization of Erwinia amylovora strains from Middle Atlas Mountains in Morocco by PCR based on tandem repeat sequences. Eur J Plant Pathol 136:665-674.

[10] Heath MC (1998) Apoptosis, programmed cell death and the hypersensitive response. Eur J Plant Pathol 104:117-124.

[11] Herlache TC (1999) Biochemical and molecular genetic investigations of the Agrobacterium vitis- grapevine interaction. Ph.D. thesis. Cornell University, Ithaca, NY.

[12] Johnson KL, D Zheng, S Kaewnum, CL Reid and T Burr (2013) Development of a magnetic camture hybridation Real-Time PCR assay for detection of Tumorigenic Agrobacterium vitis in grapevines. Plant Pathol and Plant-Micro Biol, Cornell University, Geneva, NY 14456. doi.org/10.1094/PHYTO-10-12-0267-R.

[13] Kaufmann M, HH Kassemeyer and L Otten (1996) Isolation of Agrobacterium vitis from grapevine propagating material by means of PCR after immunocapture cultivation. Vitis 35: 151-153.

[14] Kawaguchi A (2009) Studies on the diagnosis and biological control of grapevine crown gall and phylogenetic analysis of tumorigenic Rhizobium vitis. J Gen Plant Pathol 75:462.

[15] Kumagai L and AL Fabritius (2008) Detection and Differentiation of Pathogenic Agrobacterium vitis and A. tumefaciens in Grapevine using Multiplex Bio-PCR. Proceedings of the 2nd Annual National Viticulture Research Conference, University of California, Davis, USA.

[16] Kuzmanovic N, K Gasic, M Ivanovic, A Prokic and A Obradovic (2012) Identification of Agrobacterium vitis as a causal agent of grapevine crown gall in Serbia. Arch Bio Sci 64 (4): 1487-1497.

[17] Kuzmanovic N, M Ivanovic, A Prokic, K Gasic, N Zlatkovic and A Obradovic (2014) Characterization and phylogenetic diversity of Agrobacterium vitis from Serbia based on sequence analysis of 16S-23S rRNA internal transcribed spacer (ITS) region. Eur J Plant Pathol 140: 757-768.

[18]Lacroix B and V Citovsky (2013) Crown gall tumors. Brenner's Encyclopedia of Genetics 2(2): 236-239.

[19] Lamovsek J, I Zidaric, I Mavric Plesko, G Urek and S Trdan (2014) Comparative study of diagnostic methods used for monitoring of common grape vine (Vitis vinifera L.) crown gall (Agrobacterium vitis Ophel \& Kerr) on Slovenia. Acta Agric Slov doi: 10.14720/aas.2014.103.2.16.

[20]Llop P, P Caruso, J Cubero, C Morente and M Lopez (1999) A simple extraction procedure for efficient routine detection of pathogenic bacteria in plant material by polymerase chain reaction. J Micro Meth 37:23-31.

[21] Moore LW, H Bouzar and T Burr (2001) Agrobacterium. In: Schaad N.W., Jones J.B, Chun W. (eds). Laboratory Guide for Identification of Plant Pathogenic Bacteria, 3rd Ed., pp. 17-35. APS Press, St. Paul, MN, USA. 
[22] Mousavi SA, A Willems, X Nesme, P de Lajudie and K Lindstrom (2015) Revised phylogeny of Rhizobiaceae: proposal of the delineation of Pararhizobium gen. nov., and 13 new species combinations. Syst Appl Microbiol $38: 84-90$.

[23] Mousavi SA, J Osterman, N Wahlberg, X Nesme, C Lavire, L Vial, L Paulin, P de Lajudie. et al (2014) Phylogeny of the Rhizobium-AllorhizobiumAgrobacterium clade supports the delineation of Neorhizobium gen. nov. Syst Appl Microbiol 37:208-215.

[24] Ophel K and A Kerr (1990) Agrobacterium vitis sp. nov. for strains of Agrobacterium biovar 3 from grapevines. Int J Syst bacterial 40: 236-241.

[25] Pastrik KH and FA Rainey (1999) Identification and differentiation of Clavibacter michiganensis subspecies by polymerase chain reaction-based techniques. J Phyto 147:687-693.

[26] Popoff MY, K Kersters, M Kiredjian, I Miras and C Coynault (1984) Position taxonomique de souches d'Agrobacterium d'origine hospitalière. Ann Inst Pasteur Virol 135: 427-442.

[27] Rodriguez-Palenzuela P, TJ Burr and A Collmer (1991) Polygalacturonase is a virulence factor in Agrobacterium tumefaciens biovar 3. J Bacteriol 173:6547-6552.

[28] Sawada H and K Tsuchiya (2003) Taxonomy of the genus Agrobacterium. Jpn J Phytopathol 69:349365.

[29] Schroth MN, AH McCain, JH Foott and OC Huisman (1988) Reduction in yield and vigor of grapevine caused by crown gall disease. Plant Dis 72:241-246.

[30] Shams M, L Vial, D Chapulliot, X Nesme and C Lavire (2013) Rapid and accurate species and genomic species identification and exhaustive population diversity assessment of Agrobacterium spp. Using recA-based PCR. Syst Appl Microbiol 36:351-358.

[31] Shams M, T Campillo, C Lavire, D Muller, X Nesme and L Vial (2012) Rapid and efficient methods to isolate, type strains and determine species of Agrobacterium spp. in pure culture and complex environments. In Dr. Jose C. JimenezLopez (ed.)-Biochemical Testing. In Tech doi: 10.5772/2250.

[32] Szegedi, E, and S Bottka (2002) Detection of Agrobacterium vitis by polymerase chain reaction in grapevine bleeding sap after isolation on a semiselective medium. Vitis 41 (1): 37-42.

[33] Taylor RK, PJ Guilford, RG Clark, CN Hale and RLS Forster (2001) Detection of Erwinia amylovora in plant material using novel polymerase chain reaction (PCR) primers. New Zeal J Crop Horti Sci 29: 35-43.

[34] Thomashow LS, S Reeves and MF Thomashow (1984) Crown gall oncogenesis: evidence that a TDNA gene from the Agrobacterium Ti plasmid pTiA6 encodes an enzyme that catalyzes synthesis of indoleacetic acid. Proc Natl Acad Sci 81: 50715075 .

Table.1: Reactional mix preparation for the different detection protocols of A. vitis directly from plant tissues

\begin{tabular}{|c|c|c|}
\hline Protocol & Volume & Reactional mix \\
\hline 1 & 50 & $\begin{array}{l}\text { - } 24.5 \text { ultrapure water containing: BSA, } 160 \mu \mathrm{g} / \mathrm{ml} \text {, } \\
\text { (NH4)2SO4, } 16 \mathrm{mM} \text { and 2-mercaptoethanol, } 10 \mathrm{mM} . \\
\text { - } 10 \mu 1 \text { of DNA extract } \\
\text { - } 10 \mu 1 \text { PCR buffer } \times 10 \text { (Bioline) } \\
\text { - } 2.5 \mu 1 \text { dimethyl sulfoxide (DMSO) } \\
\text { - } 1 \mu 1 \text { of each primer } \\
\text { - } 0.5 \mu 1 \text { Tween } 20(100 \%) \\
\text { - } 0.5 \mu 1 \text { Taq polymerase }(5 \mathrm{U})\end{array}$ \\
\hline 2 & $50 \mu 1$ & $\begin{array}{l}\text { - } 29.76 \mu 1 \text { ultrapure water } \\
-\quad 10 \mu 1 \text { PCR buffer } \times 10 \text { (Bioline) } \\
-\quad 5 \mu 1 \text { of DNA extract } \\
-\quad 2 \mu 1 \text { Formamid } \\
-\quad 1.32 \mu 1 \text { of each primer } \\
-\quad 0.6 \mu 1 \text { Taq polymetrase }\end{array}$ \\
\hline 3,4 and 5 & $20 \mu \mathrm{l}$ & $\begin{array}{l}\text { - } \quad 9.8 \mu \mathrm{l} \text { ultrapure water } \\
-\quad 4 \mu \mathrm{l} \text { PCR buffer } \times 10 \text { (Bioline) } \\
-\quad 5 \mu \mathrm{l} \text { of macerate } \\
-\quad 0.5 \mu 1 \text { of each primer } \\
-\quad 0.2 \mu 1 \text { Taq polymerase }\end{array}$ \\
\hline
\end{tabular}




\begin{tabular}{l|l|l} 
From colony of $A$. vitis S4 & $20 \mu 1$ & $-13.8 \mu 1$ ultrapure water \\
& & $-4 \mu 1$ PCR buffer $\times 10$ (Bioline) \\
& & -1 samll colony \\
& & $-0.5 \mu 1$ from each primer \\
& & $-0.2 \mu 1$ Taq polymerase \\
\hline
\end{tabular}
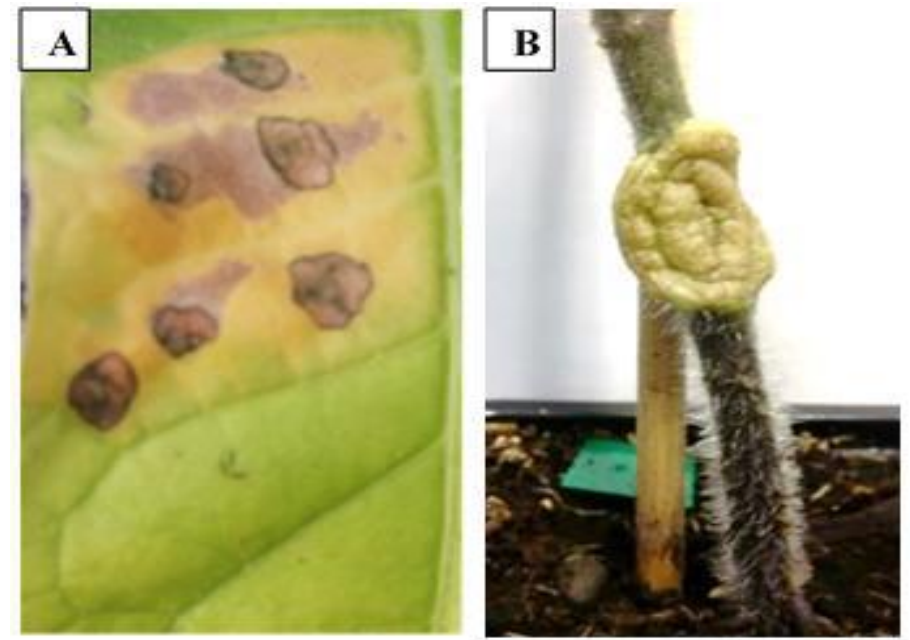

Fig.1: Hypersensibilty and pathogenicity tests of A. vitis S4. A: hypersensitive response on tobacco leaf, B: development of tumor in the stem of tomato

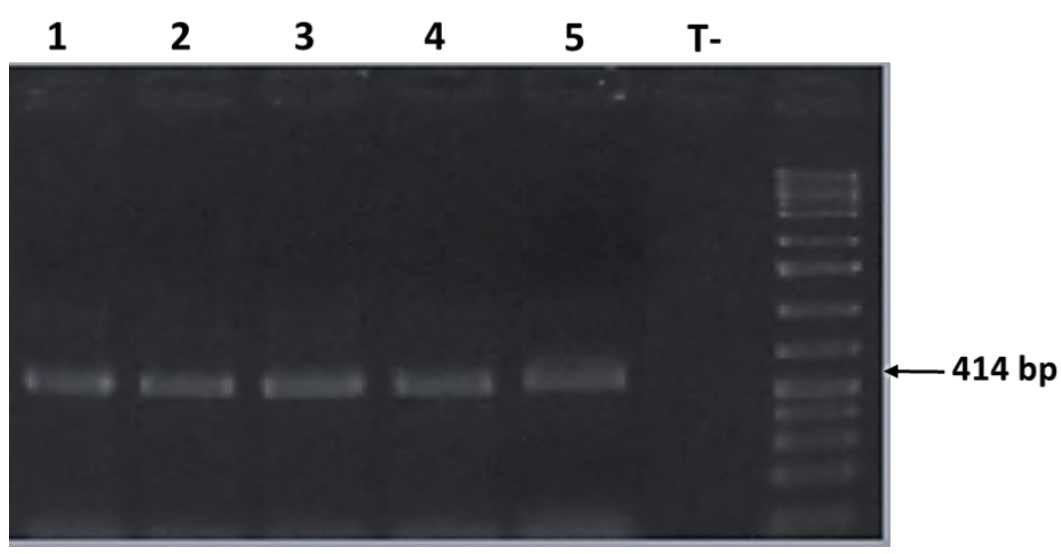

Fig.2: Electrophoritic profile of A. vitis S4 amplified with VCF3/VCR3 primers and using different protocols of DNA extraction from pure cuclture. 1: bacterial colony, 2: bacterial suspension, 3, 4 and 5: DNA extraction from pure culture using protocols 1,2 and 3 respectively.

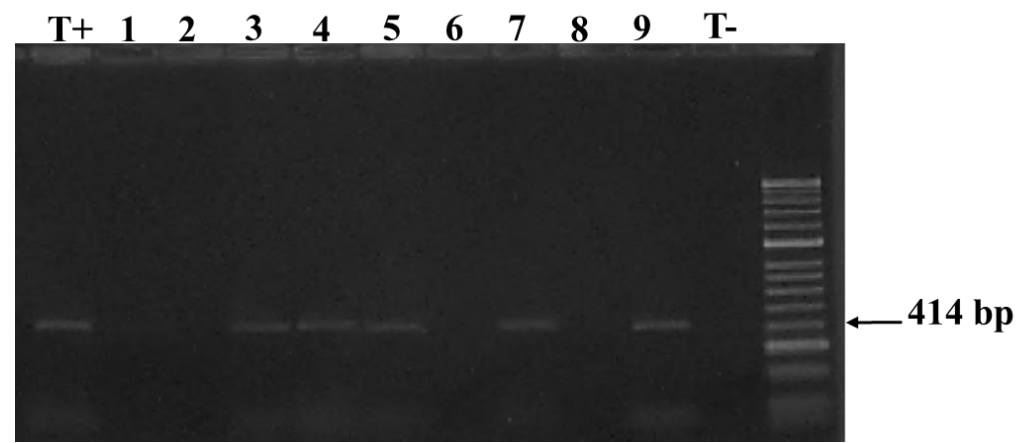

Fig.3: Electrophoritic profile of A. vitis S4 amplified with VCF3/VCR3 primers and using different protocols of DNA extraction directly from plant material (tomato tumors).

T+: positive control representing by extracted DNA from pure culture; 1, 2, 3, 4 and 5: bacterial DNA extract from plant material using protocols 1, 2, 3, 4 and 5 respectively; 6: pure macerate; 7: enriched macerate; 8 and 9: isolated colony from culture medium; $\boldsymbol{T}$-; negative control. 

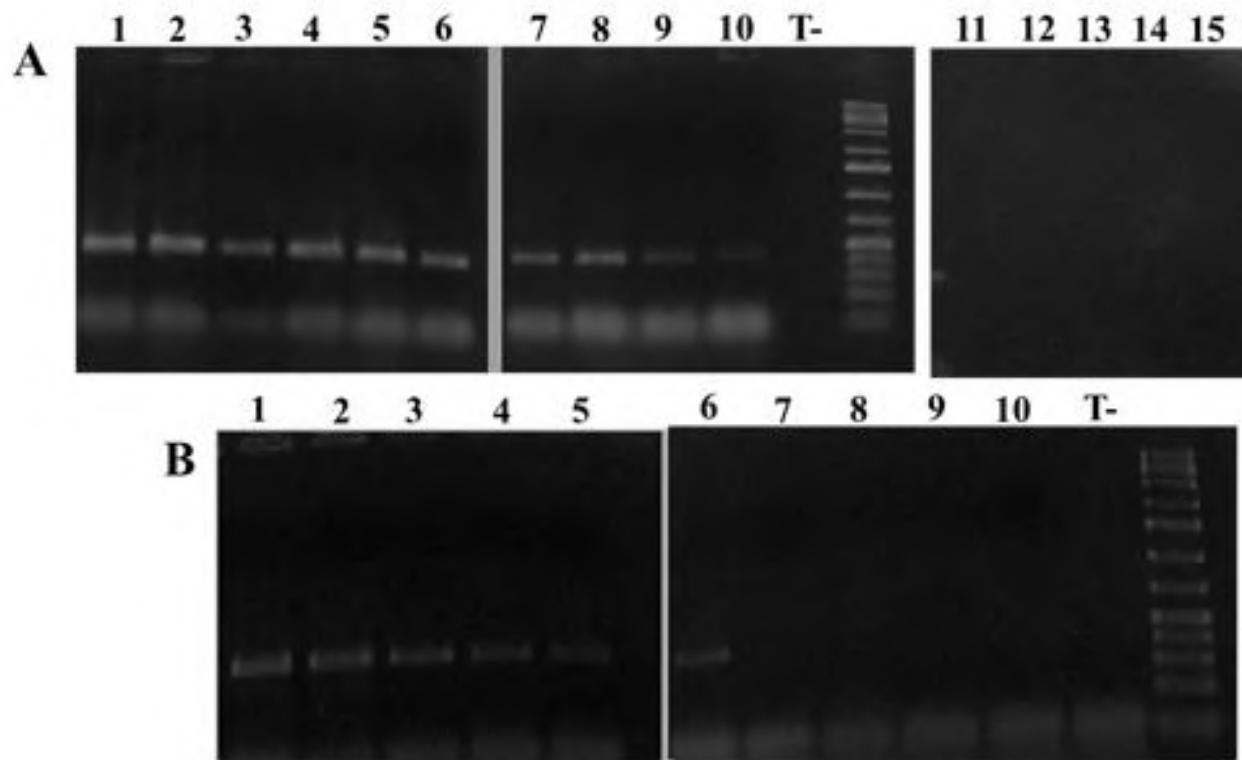

\section{$\longleftarrow 414$ bp}
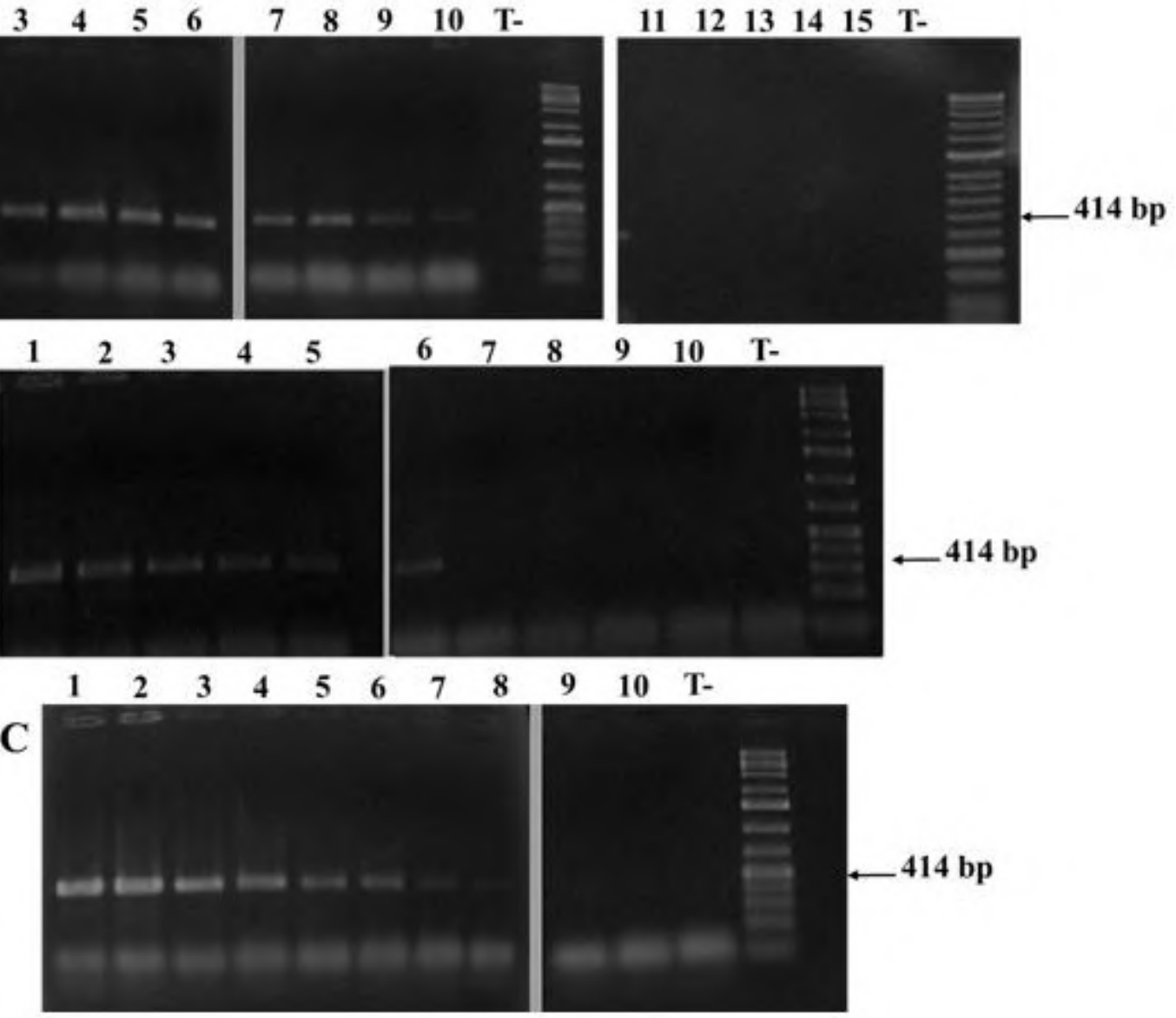

Fig.4: Evaluation of the sensitivity of different protocols of DNA extraction from pure culture. A: DNA extraction with alkaline method; B: DNA extraction with heating bacterial suspension; $\boldsymbol{C}:$ DNA extraction using thermal shock.

From 1 to 15: different concentration of bacteria $(\mathrm{CFU} / \mathrm{ml}) .1$ : $10^{9} ; 2: 5.10^{8} ; 3: 10^{8} ; 4: 5.10^{7} ; 5: 10^{7} ; 6: 5.10^{6} ; 7: 10^{6} ; 8$ : $5.10^{5} ; 9: 10^{5} ; 10: 5.10^{4} ; 11: 10^{4} ; 12: 5.10^{3} ; 13: 10^{3} ; 14: 5.10^{2} ; 15: 10^{2} ;$ T-: negative control.

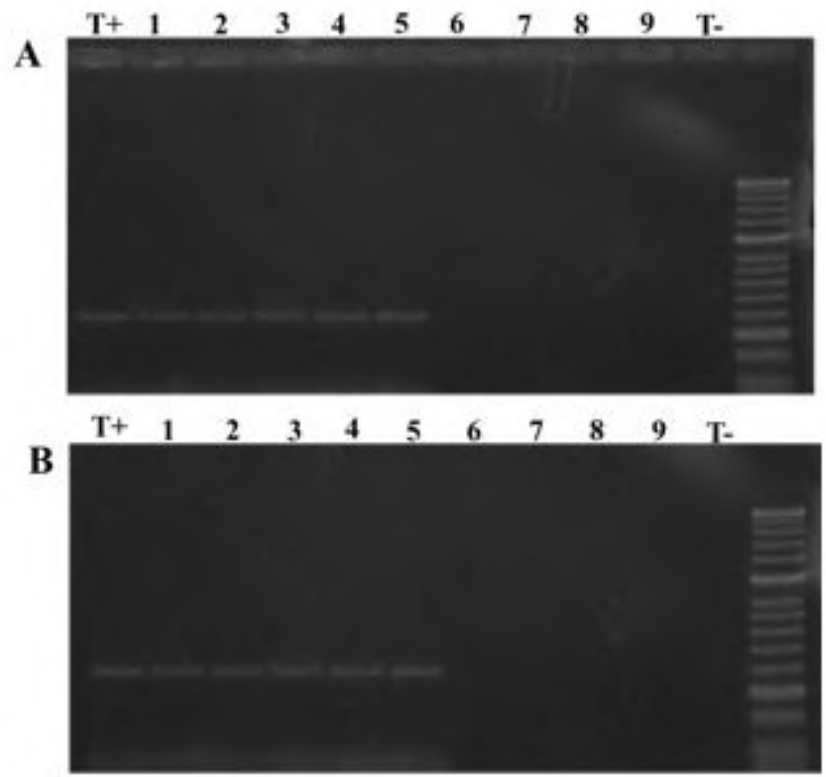

Fig.5: Evaluation of the sensitivity of different protocols of DNA extraction from plant material using, A: protocol 4 of DNA extraction with Triton X-100 and B: protocol 5 of DNA extraction with Tween 20.

T+ : positive control ; $1: 10^{7} \mathrm{CFU} / \mathrm{ml} ; 2: 10^{6} \mathrm{CFU} / \mathrm{ml} ; 3: 10^{5} \mathrm{CFU} / \mathrm{ml} ; \mathbf{4}: 10^{4} \mathrm{CFU} / \mathrm{ml} ; \mathbf{5}: 10^{3} \mathrm{CFU} / \mathrm{ml} ; \mathbf{6}: 10^{2} \mathrm{CFU} / \mathrm{ml} ; 7$ : $10 \mathrm{CFU} / \mathrm{ml} ; \mathrm{T}$ - : negative control. 